\title{
Serum Ion Regulation in Pacific Salmon Exposed to Short Term Acidwater Stress during Seaward Migratory and Post Migratory Seasons
}

\author{
Tomoharu Watanabe, ${ }^{* 1,2}$ Hitoshi Ida, ${ }^{* 2}$ and Munehico Iwata ${ }^{* 1, \dagger}$ \\ ${ }^{*}$ Nikko Branch, National Research Institute of Aquaculture, Chugushi, Nikko, Tochigi 321-16, Japan \\ ${ }^{*}$ School of Fisheries Sciences, Kitasato University, Sanriku, Iwate 022-01, Japan
}

(Received August 4, 1994) \begin{abstract}
tion
Key words: pacific salmon, acid water, seawater adaptability, osmoregulation, seaward migra-
\end{abstract}

Acid rain is causing environmental damage around major industrial areas of the world. During spring, the $\mathrm{pH}$ of river water decreases due to a steady release of hydrogen ions from accumulated pollutants in snow. The snowmelt period in spring coincides with the migratory period of salmonids, a period when salmonid fishes develop seawater adaptability with an associated parr-smolt transformation (smoltification). ${ }^{1)}$ The rapid decrease in $\mathrm{pH}$ due to snowmelt may affect the seawater adaptability of migratory salmon fry. Acid rain water has been shown to cause acute mortality, reduced growth, skeletal deformities and reproductive failure in fishes. ${ }^{2)} \mathrm{A}$ decrease in plasma sodium $\left(\mathrm{Na}^{+}\right)$and chloride $\left(\mathrm{Cl}^{-}\right)$in brown trout is also caused by acid water, caused by the thawing of snow in spring.") We examined the possible damage caused by short term acidwater stress on the osmoregulatory ability of five species of Pacific salmon during and after their migratory season.

Chum salmon fry were obtained from the Otsuchi Salmon Hatchery, Iwate. Underyearlings $\left(0^{+}\right)$of sockeye salmon and yearlings $\left(1^{+}\right)$of masu salmon, rainbow trout and steelhead trout were reared at the Nikko Branch, National Research Institute of Aquaculture. Means of body weight (migratory-post migratory periods) were $2.03 \mathrm{~g}$ (chum, the migratory periods), 7.36-16.1 $\mathrm{g}$ (sockeye), 100-141 $\mathrm{g}$ (steelhead), 54.0-76.7 $\mathrm{g}$ (masu) and 94.6-124 $\mathrm{g}$ (rainbow). A series of experiments was conducted during the migratory period (chum in April, other species in June) and the post migratory period (August; no chum after migratory season) of each species. Each species of fish was divided into four groups ( $n=10$ in each group): (1) fish from the freshwater (FW) group were sampled directly from a freshwater stock tank; (2) fish for the freshwateracidwater (FW-AW) group were transferred from a freshwater stock tank to a $130 l$ acid water $(\mathrm{pH} \mathrm{5.0;20l}$ tank for $0^{+}$fish) tank and maintained for $24 \mathrm{~h}$; (3) fish for the freshwater-seawater (FW-SW) group were transferred from a freshwater stock tank to a 90-135 $l\left(22.5 l\right.$ for $0^{+}$ fish) seawater (33\%) tank and maintained for $24 \mathrm{~h}$; (4) fish for the acidwater-seawater (AW-SW) group were exposed to acid water for $24 \mathrm{~h}$ prior to seawater exposure. The acidity of the water was regulated between $\mathrm{pH} 4.9$ and 5.1 by a
pH controller (Nissin Rika, NpH680D, Tokyo) with a perista pump titrating $1 \mathrm{~N}$ sulphuric acid. The water temperature range was $8-10^{\circ} \mathrm{C}$ (April), $10-12^{\circ} \mathrm{C}$ (June) and $10-15^{\circ} \mathrm{C}$ (August). Blood from $0^{+}$fish was collected in capillary tubes. Blood from $1^{+}$fish was collected from the caudal blood vessels by a $1 \mathrm{~m} l$ syringe. The blood was centrifuged at $10,000 \mathrm{rpm}$ for $5 \mathrm{~min}$ and the serum samples were frozen at $-80^{\circ} \mathrm{C}$. Serum $\mathrm{Cl}^{-}$concentration was determined by a chloridometer (Buchler, 4-2500) and $\mathrm{Na}^{+}$concentration was measured by an atomic absorption spectrophotometer (Hitachi, 180-50). An analysis of variance (ANOVA) and Duncan's new multiple range test were used for statistical analysis.

One out of 10 steelhead from the FW-AW group died after being transferred to acid water and three out of 10 fish from the AW-SW group died after being transferred to sea water in the post migratory period. No mortality was observed in the other groups. Except for the non-migratory species of rainbow trout, serum $\mathrm{Na}^{+}$and $\mathrm{Cl}^{-}$concentrations, when compared to controls (FW), decreased significantly $\left(p<0.01 ; p<0.05\right.$ in $\mathrm{Cl}^{-}$of masu) $24 \mathrm{~h}$ after acidwater (pH 5.0) exposure (FW-AW) during the migratory period (Fig. 1-A). Migrators of $0^{+}$chum and sockeye fry maintained their serum $\mathrm{Na}^{+}$levels at approximately $160 \mathrm{mEq} / l$ after $24 \mathrm{~h}$ in seawater (FW-SW). These levels were lower than those of $1^{+}$migrators (steelhead and masu), non-migratory rainbow trout and fishes in the post migratory period $(p<0.01)$. During the migratory period acid stressed fishes; when exposed to sea water for $24 \mathrm{~h}$ (AW-SW), their serum $\mathrm{Na}^{+}$and $\mathrm{Cl}^{-}$concentrations were similar to those of seawater controls (FW-SW) except for the $\mathrm{Na}^{+}$of chum $(p<0.01)$ and $\mathrm{Cl}^{-}$of rainbow trout $(p<0.05)$ which were significantly lower than those of the controls.

During the post migratory period (Fig. 1-B), a significant decrease in $\mathrm{Na}^{+}$concentration was observed $24 \mathrm{~h}$ after acidwater exposure (FW-AW) in the steelhead $(p<0.01)$ and rainbow trout $(p<0.05)$; a significant decrease was also observed in $\mathrm{Cl}^{-}$concentration in steelhead trout $(p<0.05)$ when compared to the control (FW). No significant difference in serum $\mathrm{Na}^{+}$and $\mathrm{Cl}^{-}$levels was detected in each species between AW-SW and FW-SW

\footnotetext{
1 To whom reprint requests should be sent.

Present address: School of Fisheries Sciences, Kitasato University, Sanriku, Iwate 022-01, Japan.
} 

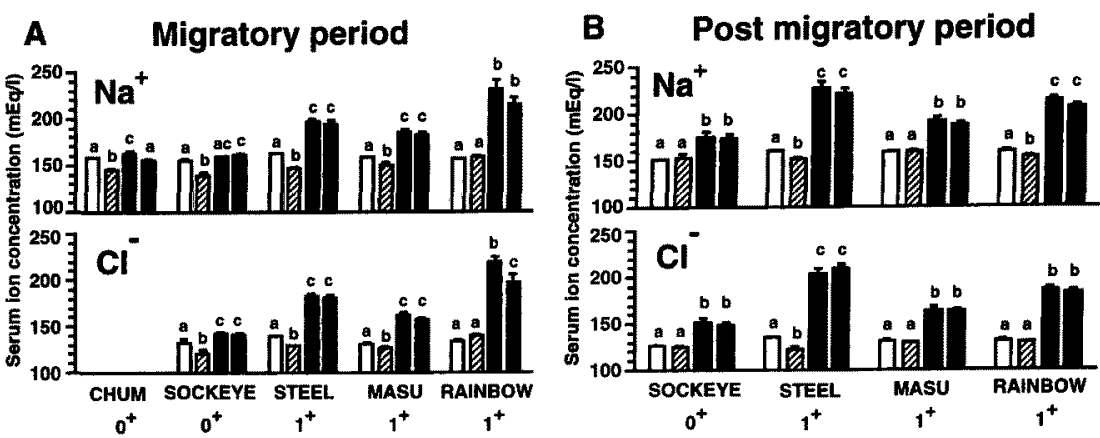

Fig. 1. Means of serum $\mathrm{Na}^{+}$and $\mathrm{Cl}^{-}$concentrations of the five species of Pacific salmon in fresh water (FW $\square$ ) or in acid water (FW-AW $\mathbb{Z}$; pH 5) for $24 \mathrm{~h}$; the concentrations of fishes in sea water for $24 \mathrm{~h}$ after transferring from fresh water (FW-SW $\square$ ) or acid water (AW-SW ${ }^{\text {) }}$ during the migratory period (A) and post migratory period (B).

Vertical bars represent standard errors $(n=10)$. Differing superscripts indicate significant differences $(p<0.05)$ between means.

when exposed to sea water for $24 \mathrm{~h}$.

Except for the steelhead trout, the low mortality of Pacific salmon exposed to acid water suggests that an acidity of pH 5.0 for $24 \mathrm{~h}$ is not lethal. Chronic acid stress (less than pH 4.0) is lethal for most fishes; it decreases the surface area of the gill epithelium and anoxia with persistent deficiency in oxygen uptake. ${ }^{4)}$ Pacific salmon had low serum $\mathrm{Na}^{+}$and $\mathrm{Cl}^{-}$levels in both the migratory and post migratory periods after exposure to acid water ( $\mathrm{pH} \mathrm{5.0)}$ for $24 \mathrm{~h}$. The loss of serum $\mathrm{Na}^{+}$and $\mathrm{Cl}^{-}$concentrations in fish may be due to an insufficient active transport at the gills and/or an increase in diffusional efflux at the gill epithelium. ${ }^{5)}$ Acid water exposure causes the membrane permeability to change at the branchial epithelium due to loss of calcium. ${ }^{6}$ The loss of serum $\mathrm{Na}^{+}$and $\mathrm{Cl}^{-}$concentrations by acidwater exposure was greater during the migratory period than the post migratory period except for the non-migratory rainbow trout in the present study. At various life stages, migratory species of Pacific salmon have less tolerance to low $\mathrm{pH}$ than non-migratory species. " Our results also show the decrease in hyper-osmoregulatory ability of migratory species in acidic freshwater. However, when fish exposed to acid water were transferred into sea water they maintained their hypo-osmoregulatory ability. Their serum $\mathrm{Na}^{+}$and $\mathrm{Cl}^{-}$ concentrations were regulated at similar levels to the seawater controls. This result suggests that $24 \mathrm{~h}$ acidwater
(pH 5.0) exposure may not affect the seawater adaptability of Pacific salmon when they migrate down to the sea. However, the salinity tolerance of smolting Atlantic salmon was depressed by acidwater ( $\mathrm{pH} \mathrm{4.2-4.7),} \mathrm{when} \mathrm{ex-}$ posed for two months. ${ }^{8)}$ Therefore, if acid pollution is predicted in the surrounding area, it would be better to release the migratory salmon into rivers near the coast to allow them to migrate down into the sea within a few days of their release.

This study was supported in part by grants from the Environment Agency (FY 1993) and Ministry of Agriculture, Forestry and Fisheries (BioCosmos BCP94-IV-B) to M. I. We thank Drs. I. S. Parhar and H. Yamada for their comments on the manuscript.

\section{References}

1) W. S. Hoar: in "Fish Physiology" (ed. by W, S. Hoar and D. J. Randoll), Vol. XIB, Academic Press, New York, 1988, pp. 275-343.

2) T. A. Haines: Trans. Am. Fish. Soc., 110, 669-707 (1981).

3) H. Leivestad and I. P. Muniz: Nature, 259, 391-392 (1976)

4) C. H. Jagoe, T. A. Haines, and F. W. Kircheis: Bull, environ. Contamin. Toxicol, 33, 430-438 (1984).

5) D. G. McDonald, R. L. Walker, and P. R. H. Wilkes: J. expl. Biol., 102, 141-155 (1983).

6) P. G. McWilliams: Comp. Biochem. Physiol., 74, 107-116 (1983).

7) P. J. Rombough: Can. J. Fish. aquat. Sci., 40, 1575-1582 (1982).

8) R. L. Saunders, E. B. Henderson, P. R. Harmon, C. E. Johnston, and J. G. Eales: Can. J. aquat. Sci., 40, 1203-1211 (1983). 